\title{
Cell-Cycle Gene Expression in Lovastatin-Induced Medulloblastoma Apoptosis
}

\author{
Wei Wang and Robert J.B. Macaulay
}

\begin{abstract}
Background: 3-hydroxy-3-methylglutaryl coenzyme A (HMG-CoA) reductase is a key rate-limiting enzyme in the mevalonate pathway, which generates precursors both for cholesterol biosynthesis and for the production of nonsteroidal mevalonate derivatives that are involved in a number of growth-regulatory processes. We have reported that lovastatin, a competitive inhibitor of HMG-CoA reductase, not only inhibits medulloblastoma proliferation in vitro, but also induces near-complete cell death via apoptosis. The mechanism of this phenomenon is unclear. Possible involvement of changes in expression of certain cell-cycle related genes led us to study some of them in more detail. Methods: Medulloblastoma cell lines were exposed in vitro to lovastatin, and the effects of gene expression changes were studied using RT-PCR, antisense oligonucleotide, DNA electrophoresis and Western blotting analysis. Results: 1) Levels of total Ras gene mRNA and individual Ras gene mRNA are stable in lovastatin treatment in all examined medulloblastoma cell lines. 2) Blocking $c-m y c$ gene over-expression does not enhance medulloblastoma cell sensitivity to lovastatin. 3) Following lovastatin treatment, $p 16$ expression exhibits no change, but pronounced increases of p27 ${ }^{K I P 1}$ protein are observed in all examined cell lines. Lovastatin induces pronounced increases of p21 WAF1 protein only in Daoy and UW228, but not in D283 Med and D341 Med. 4) Following lovastatin treatment, increased p53 protein is detected only in D341 Med, and bax protein is unchanged in all cell lines. Conclusions: Lovastatin-induced growth inhibition and apoptosis in medulloblastoma are not dependent on the regulation of Ras and $c$ - $m y c$ gene expression, but may be mediated by $p 27^{K I P I}$ gene expression. Lovastatin-induced apoptosis in medulloblastoma is probably p53 independent, but $p 53$ and $p 21^{\text {WAF1 }}$ gene expression may also mediate anti-proliferative effects of lovastatin on specific medulloblastoma cell lines.
\end{abstract}

RÉSUMÉ: Apoptose induite par la lovastatine: expression génique du cycle cellulaire dans des lignées cellulaires de médulloblastome. Introduction: La 3-hydroxy-3-méthylglutaryl-coenzyme A (HGM-CoA) réductase est un enzyme limitant clé de la voie du mévalonate qui génère des précurseurs tant pour la biosynthèse du cholestérol que pour la production de dérivés non stéroïdiens du mévalonate qui sont impliqués dans certains processus régulateurs de la croissance. Nous avons rapporté que la lovastatine, un inhibiteur non compétitif de l'HMG-CoA réductase, inhibe la prolifération du médulloblastome in vitro et induit également la mort cellulaire presque complète via l'apoptose. Le mécanisme sous-jacent à ce phénomène n'est pas clair. La possibilité que des changements dans l'expression de certains gènes du cycle cellulaire soient impliqués nous a incités à en étudier quelques-uns de plus près. Méthodes: Des lignées cellulaires de médulloblastome ont été exposées in vitro à la lovastatine et les effets des changements dans l'expression génique ont été étudiés au moyen de RT-PCR, d'oligonucléotides antisenses, de l'électrophorèse de l'ADN et du buvardage western. Résultats: 1) Les niveaux d'ARNm de tous les gènes Ras et des gènes Ras pris individuellement sont stables dans toutes les lignées cellulaires de médulloblastome étudiées après traitement par la lovastatine. 2) Le fait de bloquer la surexpression du gène c-myc n'augmente pas la sensibilité des cellules de médulloblastome à la lovastatine. 3) Suite au traitement par la lovastatine, l'expression de p16 ne change pas, mais on observe des augmentations considérables de la protéine p27KIP1 dans toutes les lignées cellulaires examinées. La lovastatine provoque des augmentations marquées de la protéine p21WAF1 dans le lignées Daoy et UW228, mais pas dans D283 Med et D341 Med. 4) Suite au traitement par la lovastatine, une augmentation de la protéine p53 est détectée seulement dans D341 Med et la protéine Bax demeure inchangée dans toutes les lignées cellulaires. Conclusions: L'inhibition de la croissance et l'apoptose induites par la lovastatine dans le médulloblastome ne sont pas dépendantes de la régulation de l'expression des gènes Ras et c-myc, mais elles pourraient être médiées par l'expression du gène p27KIP1. L'apoptose induite par la lovastatine dans le médulloblastome est probablement indépendante de p53, mais l'expression des gènes p53 et p21WAF1 peut également médier des effets antiprolifératifs de la lovastatine dans des lignées cellulaires spécifiques de médulloblastome.

Can. J. Neurol. Sci. 2003; 30: 349-357

Medulloblastoma, a primitive neuroectodermal tumor of cerebellum, accounts for about $20 \%$ of childhood intracranial tumors. ${ }^{1}$ The prognosis of patients with medulloblastoma is unpredictable and only $50-70 \%$ survive after five years., Radiation therapy is standard for medulloblastoma, but is not administered to patients less than three years old due to the
From the Laboratory of Cellular Oncology, National Cancer Institute, National Institutes of Health, Bethesda, Maryland 20892, USA (WW); Department of Pathology and Laboratory Medicine, QEII Health Sciences Center and Dalhousie University, Halifax, Nova Scotia B3H 1V8, Canada (RJBM).

ReCEIVEd DeCEMber 18, 2002. ACCEPTED IN FINAL FORM APRIL 15, 2003. Reprint requests to: Rob Macaulay, Department of Pathology, QEII HSC, Room 738, 5788 University Avenue, Halifax, NS B3H 1V8 Canada 
deleterious effects on intellectual development. ${ }^{4,5}$ Some success with adjuvant chemotherapy ${ }^{2,6}$ has been balanced by doselimiting toxicity and induction of drug resistance genes. ${ }^{7,8}$ Significantly, the mortality of recurrent medulloblastoma approaches $100 \%,{ }^{9}$ emphasizing the need for effective treatment strategies.

Lovastatin, a 3-hydroxy-3-methylglutaryl coenzyme A (HMG-CoA) reductase inhibitor, blocks the mevalonate pathway, decreasing cholesterol biosynthesis as well as the production of nonsteroidal mevalonate derivatives. ${ }^{10}$ Lovastatin has profound cellular effects, including inhibition of proliferation and induction of apoptosis, ${ }^{11-19}$ and has been used as a potential anticancer drug in clinical studies. ${ }^{20,21}$ We earlier found that lovastatin interrupts the mitotic cycle, leading to growth inhibition and the induction of apoptosis in medulloblastoma cells. ${ }^{13}$ We also demonstrated that the inhibition of mevalonate production and protein farnesylation is critical for lovastatin-induced medulloblastoma apoptosis. ${ }^{22}$ However, the sensitivity of cell lines to lovastatin varies ${ }^{13}$ for uncertain reasons, and the regulation of gene expression in lovastatin-induced growth inhibition and apoptosis is not fully understood.

The mevalonate pathway generates nonsteroidal derivatives such as geranyl and farnesyl pyrophosphate, which are required for the isoprenylation of many membrane-bound proteins like the Ras protein super family. ${ }^{23}$ Lovastatin impairs posttranslational isoprenylation of these small G-proteins, rendering such proteins unable to anchor to membranes. In yeast, the mevalonate pathway directly regulates Ras levels by controlling Ras mRNA abundance. ${ }^{24}$ Our previous results and others showed that isoprenylation inhibition increases total Ras protein levels. ${ }^{14,25}$ However, the Ras gene family is complex, and contains $N$-Ras, $K$-Ras and $H$-Ras; furthermore, the $K$-Ras gene produces two K-Ras proteins via a single alternatively spliced transcript by which either exon $4 \mathrm{a}$ or $4 \mathrm{~b}$ is spliced onto exon 3 during mRNA processing. ${ }^{26}$ The regulation of expression of these Ras genes in lovastatin-induced apoptosis is not clarified.

In medulloblastoma, lovastatin 'resistant' cell lines, D283 Med and D341 Med, ${ }^{13}$ over express $c$ - $m y c .^{27,28} \mathrm{c}$-myc normally participates in $\mathrm{G} 1$ to $\mathrm{S}$ transition, although $c$-myc gene over expression induces apoptosis when growth factor or serum is deprived. ${ }^{29-31}$ It is interesting that lovastatin dramatically reduces $c$-myc gene expression via E2F-1 modulation. ${ }^{32}$ We sought to determine whether $c-m y c$ gene over expression accounts for cell 'resistance' to lovastatin in D283 Med and D341 Med.

The expression and activity of cell cycle checkpoint proteins, particularly cyclins and cyclin-dependent kinases (Cdk), regulate transition through the cell cycle. Cyclins and Cdks in turn are regulated by the family of Cdk inhibitor proteins, such as p16, $\mathrm{p} 21^{W A F 1}$ and $\mathrm{p} 27^{K I P 1}$. p2 $1^{\text {WAFI }}$ and $\mathrm{p} 27^{K I P 1}$ appear to function as broad specificity inhibitors of cyclin/CDK complexes. p21 WAF1 induction may be either p53-dependent or -independent, and $\mathrm{p} 21^{\text {WAF1 }}$ expression induces growth inhibition and terminal differentiation. ${ }^{33-35}$ p $27^{\text {KIP1 }}$ shares partial homology with $\mathrm{p} 21^{\text {WAF1 }}$, acts as a cyclin E/CDK2 inhibitor, and is thought to mediate general anti-proliferative effects in response to certain growth inhibitory signals. ${ }^{36}$ The effects of HMG-CoA reductase inhibitors on $\mathrm{p} 21^{W A F 1}$ and $\mathrm{p} 27^{K I P 1}$ expression have been studied in different laboratories with conflicting results. . $^{32,37-43}$
Under certain conditions, inhibitors of macromolecule synthesis retard the process of apoptosis; ${ }^{44}$ thus, it has been suggested that the process of apoptosis is under some form of genetic control. Several genes that are involved in the regulation of apoptosis have been identified thus far, such as p53 and bax. p53 phosphoprotein is a transcription factor, ${ }^{45}$ which functions to promote differentiation and apoptosis in certain cellular contexts ${ }^{46}$ and acts as a cell cycle regulator which can induce cell cycle arrest in G1 phase. ${ }^{47} \mathrm{Bax} \alpha$, the principle product of bax gene, binds to $\mathrm{Bcl}-2$ and promotes apoptosis. ${ }^{48}$ p53 is a direct transcriptional activator of the human bax gene; ${ }^{49}$ thus, bax expression serves as a marker of p53-dependent apoptosis. ${ }^{50-52}$

In this study, we investigate gene expression in lovastatininduced growth inhibition and apoptosis in medulloblastoma cells, and report that 1) lovastatin has no effect on Ras gene expression; 2) $c$-myc gene over expression does not account for relative resistance of certain cell lines to lovastatin; 3) p $21^{\text {WAFI }}$ and possibly $\mathrm{p} 27^{K I P 1}$, but not $\mathrm{p} 16$, contribute to lovastatininduced growth inhibition and apoptosis; 4) lovastatin-induced apoptosis is probably p53 independent.

\section{MATERIAL AND METHODS}

Unless stated otherwise, reagents and PCR primers were obtained from Gibco BRL, Gaithersburg, MD, while RT-PCR reagents were from Perkin Elmer, Branchburg, NJ.

\section{Cell lines and culture conditions}

Medulloblastoma cell lines Daoy, D283 Med and D341 Med were all obtained from the ATCC (American type culture collection), and UW228 ${ }^{53}$ was a gift from Dr. J.R. Silber. These cells were cultured in DMEM (Dulbecco's modified Eagle's medium)/F12 nutrient mixture supplemented with $10 \%$ fetal calf serum, L-glutamine and antibiotics in a humidified atmosphere of $5 \% \mathrm{CO}_{2}$ at $37^{\circ} \mathrm{C}$.

\section{Primers used in RT-PCR}

Based on the cDNA sequences of human $K$-Ras, $H$-Ras, $N$ Ras and glyceraldehyde-3-phosphate dehydrogenase (GAPDH), primers were designed and synthesized. To detect total Ras mRNA levels, a common sequence for K-Ras4A, K-Ras4B, HRas and N-Ras mRNA was used for primers. The antisense primer for total Ras mRNA was 5'-AATTTGCTC TCTGTAGTGGT-3', corresponding to a consensus bridging exons 2 and 3 in all Ras genes (primer RT1); the sense primer was 5'-TGACGGAATATAAACTGGTG-3' corresponding to a sequence located at the beginning of the first exon of all Ras genes (primer F1). The expected product was $299 \mathrm{bp}$. The primer RT1 was used in combination with sense primer 5'GGAGATAGGCATGCTGAAA-3' (primer F2) for K-Ras mRNA (K-Ras4A and K-Ras4B). The expected product was 319 bp. RT1 combining with sense primer 5'-GATCTTGAG GTTATTGCTG-3' (primer F3) were used for N-Ras mRNA, producing a $326 \mathrm{bp}$ product. RT1 and sense primer 5'TAGGTCAGGAGAACCTGTA-3' (primer F4) was used for $\mathrm{H}$ Ras mRNA, producing a 353 bp product. As an internal standard, GAPDH was used with the antisense primer 5'-CTCAGTGTA GCCCAGGATGC-3' (primer RT2) and the sense primer 5'ACCACCATGGAGAAGGCTGG-3' (primer F5). The expected product was $528 \mathrm{bp}$. 


\section{Antisense and sense c-myc oligonucleotides}

Based on the cDNA sequence of $c-m y c$, the oligonucleotide 5'-AAC GTT GAG GGG CAT-3' is complementary to the translation initiation site of c-myc mRNA. This was used as a $c$ $m y c$-specific antisense inhibitor of translation. A sense oligonucleotide 5'-ATG CCC CTC AAC GTT-3' with a secondary structure identical to that of the antisense oligonucleotide served as a control. The antisense oligonucleotide used in this experiment has been successfully used previously by other groups for specific inhibition of $c-m y c$ expression. ${ }^{54-58}$ To increase stability of oligonucleotides, both antisense and sense oligonucleotides were modified with phosphothioate.

\section{Lovastatin administration}

Cells were grown to sub-confluency in flasks, then treated with lovastatin (kindly provided by W.L. Henckler, Merck Research Laboratories, Rahway, NJ, USA). Lovastatin was prepared as previously described. ${ }^{11}$ For attached cell lines, media was aspirated and replenished with fresh medium containing varying concentrations of lovastatin. For suspended or partially attached cell lines, floating cells were aspirated, spun and resuspended in medium, then returned to the flasks containing varying concentrations of lovastatin. Vehicle treatment was used as control.

\section{RT-PCR analysis of Ras mRNA levels}

After cellular RNA was extracted from lovastatin-treated medulloblastoma cells using the acid guanidinium-phenolchloroform method with the TriZol reagent according to the manufacturer's instructions, relative levels of Ras mRNA were measured using a semi-quantitative reverse transcriptasepolymerase chain reaction (RT-PCR) method. The levels of GAPDH mRNA were measured in parallel as internal control. For cDNA generation, total cellular RNA $(1 \mu \mathrm{g})$ was carried in $20 \mu \mathrm{l}$ reaction containing $1 \mathrm{x}$ PCR buffer with $5 \mathrm{mM} \mathrm{MgCl}_{2}, 1$ $\mathrm{mM}$ each of deoxynucleotide triphosphates (dNTP), 20 units RNase inhibitor, 50 units of MuLV reverse transcriptase and 50 pMol of random hexamer oligodeoxynucleotides. After preincubation at $21^{\circ} \mathrm{C}$ for 10 minutes, the reaction was performed for 15 minutes at $42^{\circ} \mathrm{C}$, followed by $99^{\circ} \mathrm{C}$ for five minutes on Perkin-Elmer GeneAmp PCR System 2400. For cDNA amplification, PCR was performed on the above PCR System in $50 \mu \mathrm{l}$ of reaction containing $2 \mu \mathrm{l}$ of cDNA products as template DNA, 1 x PCR buffer with $2 \mathrm{mM}$ of $\mathrm{MgCl}_{2}$, additional $50 \mu \mathrm{M}$ of each dNTP, 1.25 units of Ampli Taq Gold ${ }^{\text {TM }}$ DNA polymerase, 20 pMol of GAPDH primers and 50 pMol of Ras primers. Following pre-incubation at $95^{\circ} \mathrm{C}$ for nine minutes, amplification proceeded for serial cycles (30 to 41) consisting of $94^{\circ} \mathrm{C}$ for 30 sec, $49^{\circ} \mathrm{C}$ for $20 \mathrm{sec}, 72^{\circ} \mathrm{C}$ for $30 \mathrm{sec}$, to obtain data within the linear range of the assay. After the last cycle, samples were incubated for seven minutes at $72^{\circ} \mathrm{C}$ to extend incomplete products. An aliquot of each PCR product was size-fractionated by electrophoresis in $1.4 \%$ agarose gel.

\section{Antisense c-myc treatment of medulloblastoma cells}

After medulloblastoma cells were grown to sub-confluency in flasks, they were treated for 12 hours with $25 \mu \mathrm{M}$ antisense oligonucleotide or sense oligonucleotide. Following this treatment, medium was removed, floating cells were collected and resuspended in medium, then returned to the flasks containing $20 \mu \mathrm{M}$ lovastatin plus $25 \mu \mathrm{M}$ antisense oligonucleotide or sense oligonucleotide. After treatment at varying time points, cells were harvested for DNA analysis.

\section{DNA assays}

Antisense $c$-myc treated cells were harvested at the indicated time points. DNA was extracted and assessed by electrophoreses as previously described. ${ }^{13}$

\section{Western blotting}

Western blotting was performed as previously described. ${ }^{14}$ Briefly, cells were treated with lovastatin and harvested. Cell pellets were washed four times with ice cold phosphate buffered saline, lysed in RIPA-NP40 lysis buffer $(50 \mathrm{mM}$ Tris- $\mathrm{HCl}, \mathrm{pH}$ 8.0, $150 \mathrm{mM} \mathrm{NaCl}, 1 \% \mathrm{NP} 40,1 \%$ Doc, $0.1 \%$ SDS, $2.5 \mathrm{mM}$ EDTA, $1 \mathrm{mM}$ PMSF) according to a modification of a previously described method. ${ }^{59}$ Protein concentrations were determined by BioRad (Hercules, CA) DC protein assay according to the manufacturer's instructions. Lysates were electrophoresed on $10 \%$ SDS-polyacrylamide gels and transferred to nitrocellulose membrane. For each blot, protein was equally loaded across all lanes as follows: c-myc, $30 \mu \mathrm{g}$; p16, $40 \mu \mathrm{g}$; p21, $20 \mu \mathrm{g}$; p27, $25 \mu \mathrm{g}$; p53,30 $\mu \mathrm{g}$; and bax, $50 \mu \mathrm{g}$.

Membranes were blocked in Tris-buffered saline containing $5 \%$ skim milk and $0.05 \%$ Tween-20 (TBST) overnight at $4^{\circ} \mathrm{C}$ prior to incubation with antibodies against p53 (DAKO Diagnostics Canada Inc., Mississauga, ON), or p27 ${ }^{K I P 1}$ (DAKO Diagnostics Canada Inc., Mississauga, ON), or p21 ${ }^{\text {WAFl }}$ (Ab-1) (Oncogene Science Diagnostics, Cambridge, MA), or c-myc (Ab-1) (Oncogene Science Diagnostics, Cambridge, MA), or bax (Oncogene Science Diagnostics, Cambridge, MA), or p16 (Pharmingen Canada, Mississauga, ON) in $0.5 \%$ skim milkTBST. Development was accomplished using a biotinylated secondary antibody (Vectastain ABC-AP Reagent; Vector, Burlingame, $\mathrm{CA}$ ) and $\mathrm{BCIP} / \mathrm{NBT}$ according to the manufacturer's instructions.

\section{Densitometry}

Experiments were run in duplicate, and informative bands were quantified twice using a gel documentation system (Gel Doc 2000, Bio-Rad Laboratories, Mississauga, ON). Western blotting for $c$-myc yielded the expected $65 \mathrm{kDa}$ band, as well as an inconsistent shadow band at $76 \mathrm{kDa}$. The latter was not quantified since it may be nonspecific, but it tended to reflect the changes observed in the $65 \mathrm{kDa}$ band.

\section{RESUlts}

\section{Lovastatin does not affect $R$ as gene expression}

Ras mRNA levels were analyzed by RT-PCR in cell lines treated with lovastatin. At time points of $20 \mu \mathrm{M}$ of lovastatin sufficient to induce apoptosis, ${ }^{13,14,22}$ the total Ras mRNA levels showed constitutive levels without any demonstrable change (Figure 1). Furthermore, with varying concentrations of lovastatin treatment, total Ras mRNA levels failed to show any consistent change, compared with control cells (data not shown). This finding indicates that Ras gene transcription or total mRNA is stable despite the blockage of Ras protein isoprenylation. However, it does not exclude the possibility that particular Ras 


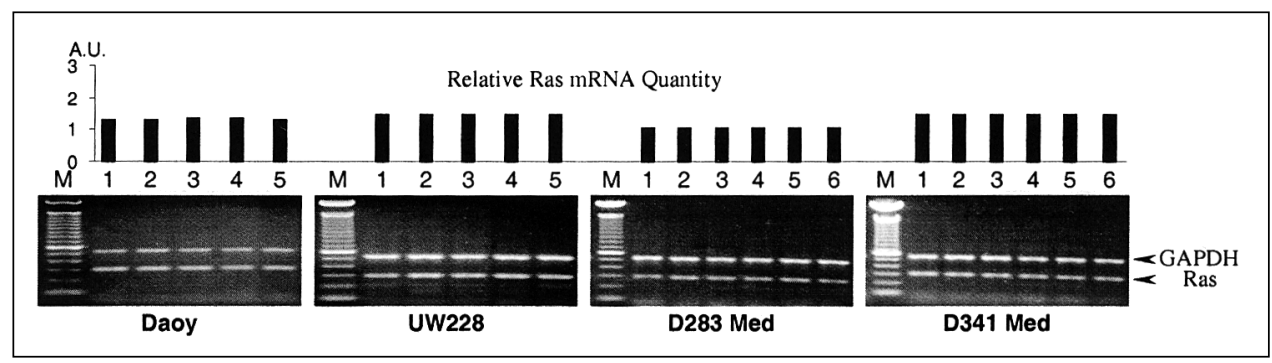

Figure 1: RT-PCR for total Ras $m R N A$ in medulloblastoma cells treated with 20 $\mu M$ of lovastatin for indicated time intervals. The relative Ras expression was normalized to GAPDH expression after densitometric analysis of the bands. (Columns: means of two different experiments, each measured twice). GAPDH: 528 bp; Ras: 299 bp. Time intervals for lanes: 1) time 0 ; 2) $6 \mathrm{hr}$; 3) $12 \mathrm{hr}$; 4) $24 \mathrm{hr}$; 5) $48 \mathrm{hr}$ in D283 Med and D341 Med, or untreated $x 24 \mathrm{hr}$ in Daoy and UW228; 6) untreated $x 48 \mathrm{hr}$ in D283 Med and D341 Med. M: Marker. A.U.: arbitrary units.

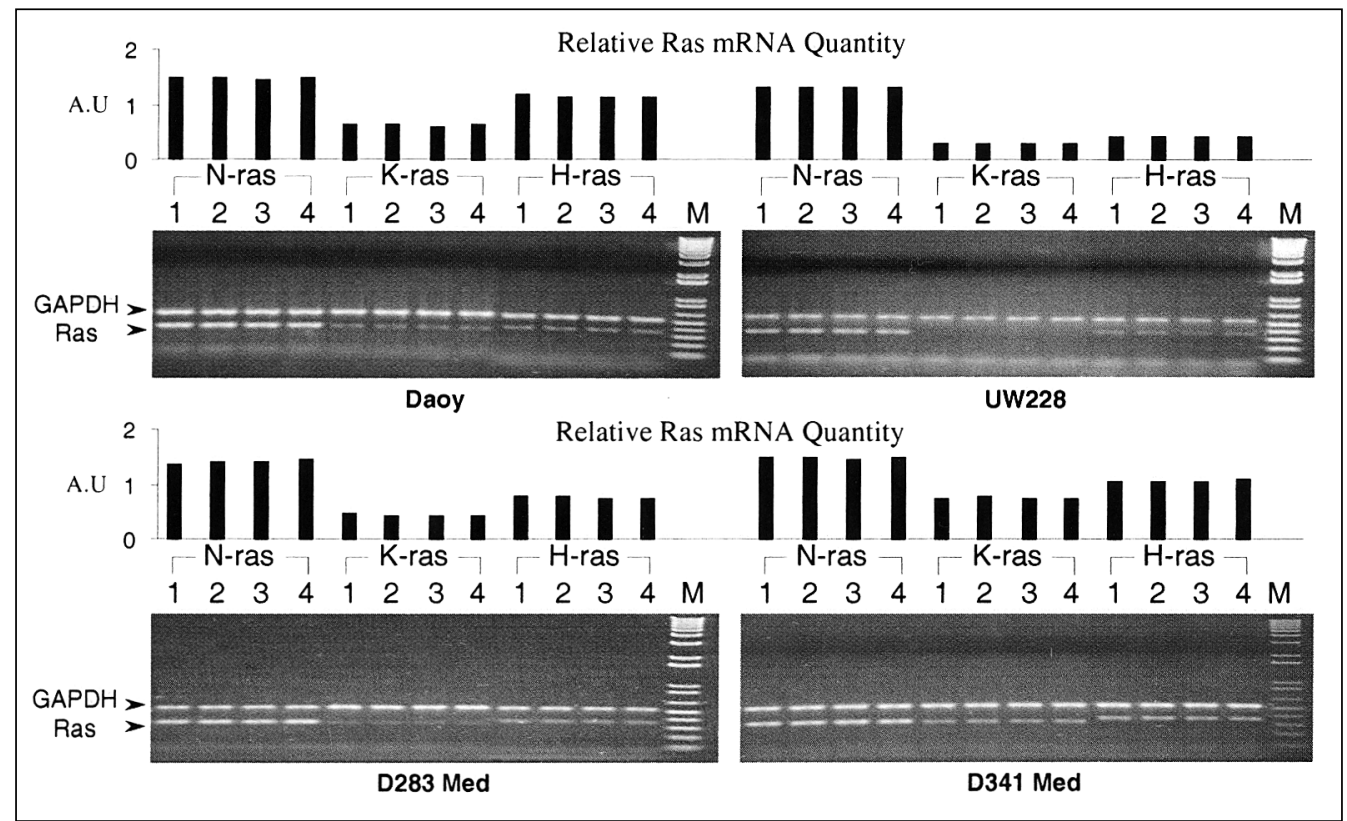

Figure 2: RT-PCR for $N$-, $K$ - and H-Ras mRNA in medulloblastoma cells treated with $20 \mu M$ of lovastatin. The relative Ras expression was normalized to GAPDH expression after densitometric analysis of the bands. GAPDH: 528 bp; N-Ras: 326 bp; K-Ras: 319 bp; H-Ras: 354 bp. Lanes: in Daoy and UW228: 1) lovastatin $x$ $12 \mathrm{hr}$; 2) lovastatin $x 24 \mathrm{hr}$; 3) vehicle $x 24 \mathrm{hr}$; 4) untreated $x 24 \mathrm{hr}$. Lanes in D283 Med and D341 Med: 1) lovastatin $\times 24 \mathrm{hr}$; 2) lovastatin $\times 48 \mathrm{hr}$; 3) vehicle $\times 48 \mathrm{hr}$; 4) untreated $48 \mathrm{hr}$. M: Marker. A.U.: arbitrary units.

Figure 3: Western blotting for c-myc expression in medulloblastoma cells. $30 \mu \mathrm{g}$ of cell lysates of each cell line were loaded. The relative expression in each cell line was normalized to the level of c-myc in UW228 after densitometric analysis of the bands. Lane 1: Daoy; Lane 2: UW228; Lane 3: D283 Med; Lane 4: D341 Med. A.U.: arbitrary units.

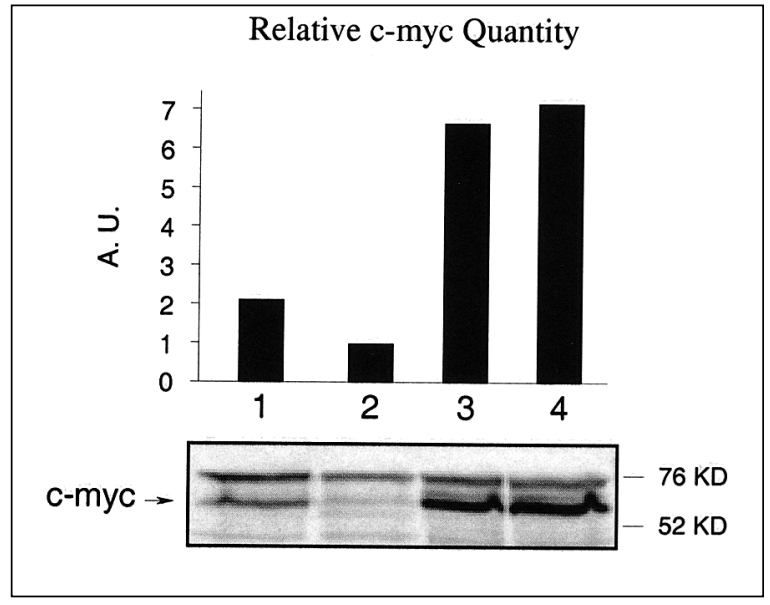




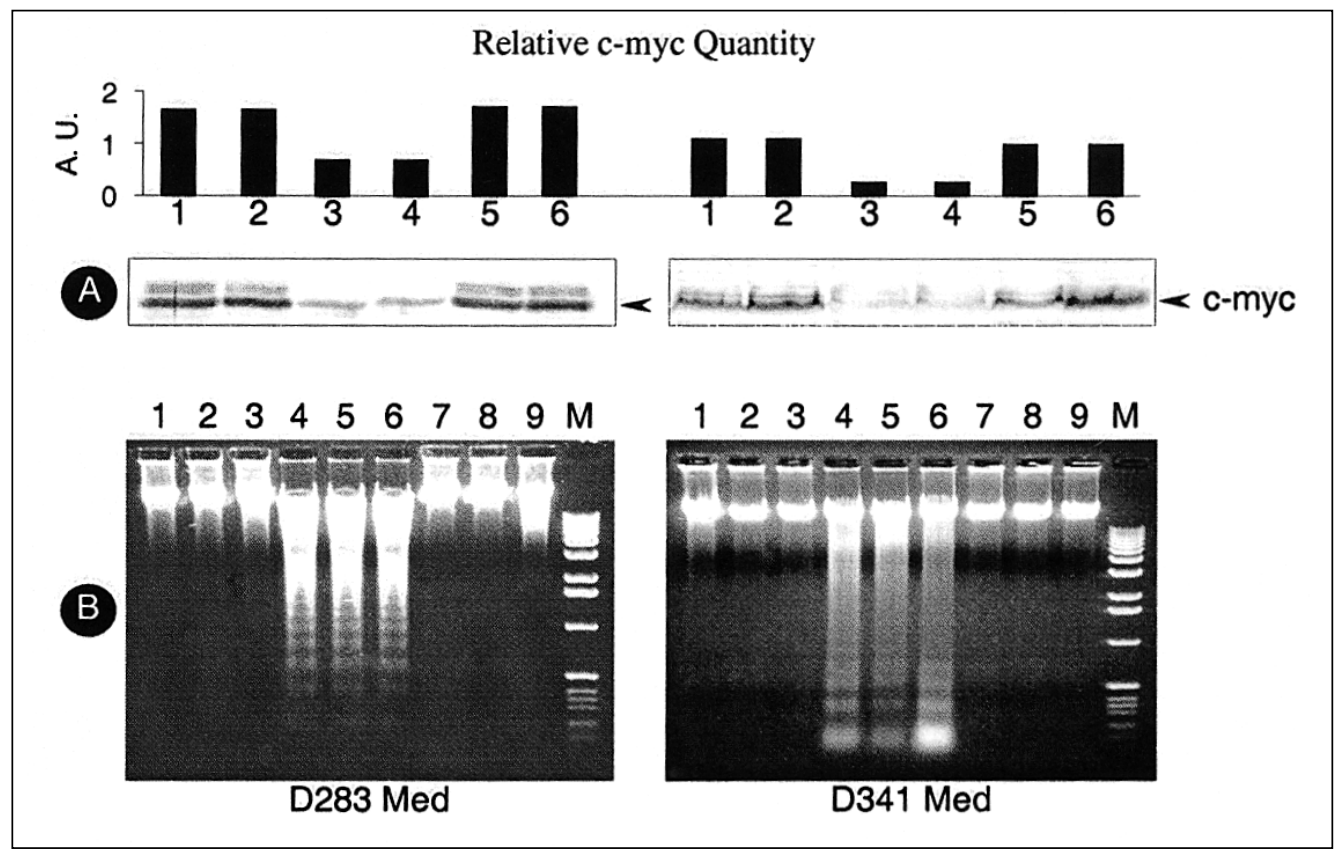

Figure 4: c-myc expression and lovastatin-induced apoptosis. Left pattern represents D283 Med, right pattern is for D341 Med. All test cell lines were treated with $20 \mu \mathrm{M}$ lovastatin, $25 \mu \mathrm{M}$ c-myc antisense or sense oligonucleotides for the stated time interval. A: Western blotting for C-myc. The relative level of c-myc protein of D283 Med and D341 Med cells in each treatment was normalized to the level of c-myc in untreated cells after densitometric analysis of the bands. B: Agarose gels of DNA laddering. Lanes in A show $48 \mathrm{hr}$ treatment of D283 and $60 \mathrm{hr}$ treatment of D341 Med, which are (1) Untreated; (2) sense c-myc; (3) antisense c-myc; (4) lovastatin plus antisense c-myc; (5) lovastatin plus sense c-myc; (6) Lovastatin. Lanes in $B:$ (1) lovastatin plus antisense c-myc, D283 Med x $48 \mathrm{hr}$, D341 Med x $60 \mathrm{hr}$; (2) lovastatin plus sense c-myc, D283 Med x $48 \mathrm{hr}$, D341 Med x $60 \mathrm{hr}$; (3) lovastatin, D283 Med x $48 \mathrm{hr}$, D341 Med x $60 \mathrm{hr}$; (4) lovastatin plus antisense c-myc, D283 Med x $72 \mathrm{hr}$, D341 Med x $84 \mathrm{hr}$; (5) lovastatin plus sense c-myc, D283 Med x 72 hr, D341 Med x 84 hr; (6) lovastatin, D283 Med x 72 hr, D341 Med x 84 hr; (7) antisense c-myc, D283 Med x 72 hr, D341 Med x 84 hr; (8) sense cmyc, D283 Med x 72 hr, D341 Med $x 84$ hr; (9) Untreated D283 Med x72 hr, D341 Med x 84 hr. M: Marker. A.U.: arbitrary units.

genes may have been differentially regulated by mevalonate derivatives.

To address this question, relative levels of N-Ras, K-Ras and H-Ras mRNA were assessed with RT-PCR in lovastatin-treated cells. No appreciable change of individual Ras mRNA was observed after lovastatin treatment compared to control (Figure 2). $N$-Ras and $H$-Ras gene expression was similar when cell lines were compared to one another; however, $K$-Ras gene expression was low in each cell line, and was difficult to detect in UW228 and D283 Med. Although $N$-Ras gene expression appeared higher than $K$-Ras and $H$-Ras expression, this comparison may be inaccurate due to differences in conditions and primer characteristics among these experiments.

\section{$c$-myc over expression does not account for medulloblastoma resistance to lovastatin}

As previously reported, D283 Med and D341 Med were relatively resistant to lovastatin, compared to UW228 and Daoy. ${ }^{13}$ In attempting to explain this difference, note was made of differences in the reported genetic backgrounds between the different cell lines. $c$ - $m y c$ gene is over expressed in D283 Med and D341 Med. ${ }^{27,28}$ Western blotting confirmed that $c-m y c$ is relatively highly expressed in D283 Med and D341 Med, compared to sensitive cell lines Daoy and UW228 (Figure 3), raising the possibility that $c$-myc gene over expression may confer relative resistance to lovastatin.

Following the treatment with $25 \mu \mathrm{M}$ of $c$-myc antisense oligonucleotides on D283 Med and D341 Med, $c$-myc gene expression was markedly blocked (Figure 4A lanes 3 and 4), compared to its expression in cells without antisense $c$-myc treatment (Figure 4A lanes 1 and 6) and $c$-myc sense oligonucleotides treated cells (Figure 4A lanes 2 and 5). However, blocking $c-m y c$ gene expression did not increase the sensitivity of D283 Med and D341 Med to lovastatin. Apoptotic DNA fragmentation occurred after lovastatin treatment 72 hours for D283 Med and $84 \mathrm{hr}$ for D341 Med; similarly, DNA laddering was seen when $25 \mu \mathrm{M}$ of $c-m y c$ antisense or sense oligonucleotides accompanied $20 \mu \mathrm{M}$ lovastatin of D283 Med for $72 \mathrm{hr}$ and D341 Med for $84 \mathrm{hr}$ (Figure 4B lanes 4, 5 and 6). Blocking $c$-myc expression with $c-m y c$ antisense oligonucleotides did not shorten the time required for lovastatininduced DNA fragmentation (Figure 4B lane 1), compared to lovastatin alone (Figure 4B lane 3). c-myc sense oligonucleotide had no effect (Figure 4B lane 2). Like untreated control cells (Figure 4B lane 9), no DNA laddering was evident after administration of $c-m y c$ antisense and sense oligonucleotides 


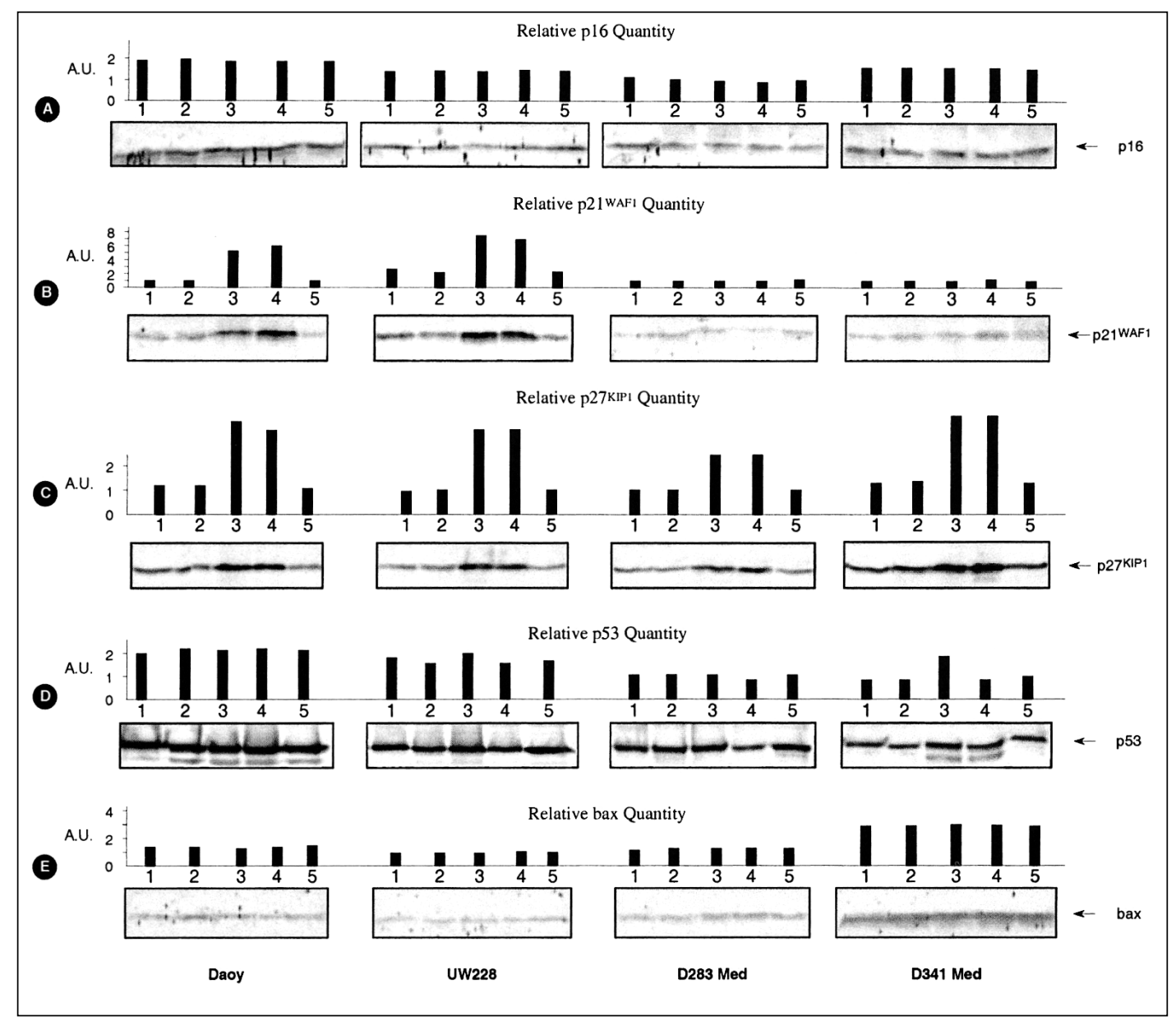

Figure 5: Western blotting for lovastatin-induced changes of $p 16, p 21^{\text {WAFI }}, p 27^{K I P 1}$ and $p 53$ as well as bax Expression. A: p16 protein. B: $p 21^{\text {WAFI }}$ protein. C: $p 27^{K I P I}$ protein. D: $p 53$ protein. E: bax protein. Protein expression was detected after $20 \mu \mathrm{M}$ lovastatin treatment for varying intervals. The relative level of $p 16, p 21^{W A F I}, p 27^{K I P I}$ and $p 53$ as well as bax protein of lovastatin-treated medulloblastoma cells was normalized to their level in vehicle treated cells after densitometric analysis of the bands. Time intervals for lanes: (1) Untreated $x 24 \mathrm{hr}$; (2) Untreated, $x 36 \mathrm{hr}$ in Daoy and UW228, $x 72 \mathrm{hr}$ in D283 Med and D341 Med; (3) Lovastatin, $x 24$ in Daoy and UW228, $x 48 \mathrm{hr}$ in D283 Med and D341 Med; (4) Lovastatin, $x 36 \mathrm{hr}$ in Daoy and UW228, $x 72 \mathrm{hr}$ in D283 Med and D341 Med; (5) Vehicle of lovastatin, $x 36$ hr in Daoy and UW228, $x 72 \mathrm{hr}$ in D283 Med and D341 Med. A.U.: arbitrary units.

alone (Figure 4B lanes 7 and 8). Lovastatin treatment had no effect on the level of $c-m y c$ protein (Figure 4A lane 1 and 6).

\section{Cdk inhibitor regulation of lovastatin-induced growth inhibition and apoptosis}

Following $20 \mu \mathrm{M}$ of lovastatin treatment, p16 expression exhibited no change by Western blotting (Figure 5), indicating that p16 was not responsible for lovastatin-induced growth inhibition and apoptosis. In contrast, Western blotting showed that $20 \mu \mathrm{M}$ lovastatin induced pronounced increases of $\mathrm{p} 21^{\mathrm{WAF} 1}$ expression in Daoy and UW228 while p $21^{W A F 1}$ protein was stable in lovastatin-treated D283 Med and D341 Med (Figure 5). These results suggested a role for $\mathrm{p} 21^{\mathrm{WAF} 1}$ over expression in lovastatin-induced growth inhibition and apoptosis in Daoy and UW228. Furthermore, $20 \mu \mathrm{M}$ lovastatin resulted in pronounced increases of p27 ${ }^{K I P 1}$ protein in all cell lines (Figure 5). These results suggest a role for $\mathrm{p} 27^{\text {KIP1 }}$ in lovastatin-induced growth inhibition and apoptosis, possibly adding to the effects of increased p21 ${ }^{\mathrm{WAF} 1}$ expression in Daoy and UW228.

\section{p53 and bax expression in lovastatin-induced apoptosis}

Increased p53 expression was detected by Western blotting after administration of $20 \mu \mathrm{M}$ lovastatin in D341 Med (48 hr). In contrast, no change was detected in either Daoy, UW228 or D283 Med treated with $20 \mu \mathrm{M}$ lovastatin (Figure 5). However, p53 levels were reduced to normal, even to below baseline, after longer treatments with lovastatin (36 hr for Daoy and UW228, $72 \mathrm{hr}$ for D283 Med and D341 Med). p53 levels were stable in untreated controls and vehicle treated controls. Results varied among cell lines, and the timing of changes mitigated against a consistent effect. Despite the increase in p53 expression following lovastatin treatments in D341 Med, Western blotting 
failed to show changes in bax expression in any cell line (Figure 5), suggesting that lovastatin-induced apoptosis is probably p53 independent.

\section{Discussion}

Lovastatin has, in recent years, gained more attention as an anticancer agent. We have already shown its anti-proliferative effects on medulloblastoma. ${ }^{13,14,22}$ In this study, we have attempted to disentangle the complex molecular regulatory mechanisms of these effects. We investigated: 1) Ras gene expression in lovastatin-induced growth inhibition and apoptosis; 2) the participation of c-myc over expression in relative lovastatin resistance of two medulloblastoma cell lines; 3) the contribution of $\mathrm{Cdk}$ inhibitors to lovastatin-induced growth inhibition and apoptosis; and 4) the role of p53 in lovastatin-induced growth inhibition and apoptosis.

\section{Ras gene expression in lovastatin-induced growth inhibition and apoptosis}

Inhibition of HMG-CoA reductase by lovastatin depletes mevalonate production, and then alters the post-translational processing of CAAX-containing small G-proteins including Ras protein. ${ }^{60,61}$ We reported that Ras protein levels were increased upon lovastatin treatment, ${ }^{14}$ postulating that this was due to Ras gene over expression, since the mevalonate pathway directly regulates Ras levels by controlling Ras mRNA abundance. ${ }^{24}$ However, in this report, semiquantative RT-PCR for N-, K- and H-Ras revealed that lovastatin does not affect either total Ras gene or specific Ras gene expression in medulloblastoma. Thus, changes in Ras gene expression are not implicated in lovastatininduced medulloblastoma apoptosis; rather, the lovastatininduced increase of Ras protein level is probably due to the regulation of translation and post-translational degradation. ${ }^{25}$ Expression of N-Ras and K-Ras may account for some Ras processing despite farnesylation inhibition, ${ }^{14}$ because they may be geranylgeranylated when protein farnesylation is inhibited. ${ }^{62,63}$

\section{Participation of c-myc over expression in relative lovastatin resistance}

Expression of the myc transcription factor is important for cell proliferation $;{ }^{64}$ myc has also been implicated in the induction of apoptosis under certain conditions that cause growth inhibition, such as growth factor and serum deprivation. ${ }^{29-31} \mathrm{~A}$ number of reports have focused on the oncogenic activity of myc proteins. Myc interacts with the retinoblastoma protein (pRB) and is able to override pRB-induced cell cycle arrest. myc over expression results in uncontrolled cell proliferation. ${ }^{65}$ Since cell proliferation is induced when $m y c$ is expressed in the presence of certain growth promoting factors, and our culture media are supplemented with fetal bovine serum, we postulated that $c$-myc over expression in D283 Med and D341 Med confer relative resistance to lovastatin-induced apoptosis. However, this does not appear to be the case, since blocking $c$-myc expression with antisense oligonucleotides did not affect sensitivity of these cell lines to lovastatin. This is consistent with data showing that the effect of lovastatin on neuroblastoma appears to be independent of the level of $N$-myc expression. ${ }^{66}$ Our data show that $c$-myc protein level is stable in lovastatin treatment, indicating lovastatin has no effect on $c-m y c$ gene expression, in contrast to recently published data showing that lovastatin down-regulates $c$-myc gene expression in the human prostate carcinoma cell PC$3{ }^{32}$ This is likely cell type dependent. Further evidence of the relationship between lovastatin and $c-m y c$ gene expression remains to be addressed.

\section{Contribution of Cdk inhibitors to lovastatin-induced growth inhibition and apoptosis}

Recent studies have tried to explore how Cdk inhibitors and p53 expression relate to lovastatin-induced growth inhibition and apoptosis, ${ }^{18,32,37-43,67,68}$ but the results are varied. We previously demonstrated cell-cycle arrest following lovastatin treatment of medulloblastoma cell lines. ${ }^{13}$ To study these proteins in lovastatin treatment of medulloblastoma, we investigated p16, $\mathrm{p} 21^{\mathrm{WAF} 1}, \mathrm{p} 27^{\mathrm{KIP} 1}$, and p53 as well as bax expression. Our studies demonstrated that the accumulation of $\mathrm{p} 21^{\mathrm{WAF} 1}$ and $\mathrm{p} 27^{\mathrm{KIP} 1}$ proteins, but not p16, accompany lovastatin treatment, correlating with growth inhibition and apoptosis, consistent with several reports from other investigators. ${ }^{37-43}$ However, p2 $1^{\text {WAF1 }}$ protein is increased only in Daoy and UW228, but not in D283 Med or D341 Med with lovastatin treatment, suggesting that $p 21^{W A F 1}$ gene over expression mediates the antiproliferative effects of lovastatin in a cell type dependent manner. This may explain why some reports showed that lovastatin induces the increase of $\mathrm{p} 21^{\mathrm{WAF} 1}$ protein, ${ }^{39-42}$ while others did not. ${ }^{32,69}$ Since $\mathrm{p} 27^{\mathrm{KIP} 1}$ protein is inducible and increased in all test cell lines treated with lovastatin, $\mathrm{p} 27^{\mathrm{KIP} 1}$ is likely a major player to mediate growth inhibition and apoptosis in lovastatin treatment, consistent with other reports. ${ }^{37-40,43}$

\section{Role of p53 in lovastatin-induced growth inhibition and apoptosis}

Despite the increase in p53 expression following lovastatin treatments in D341 Med, the level of bax protein in all examined cell lines was stable during lovastatin treatment. This is not consistent with one report that p53 and bax were induced in lovastatin-induced neuronal apoptosis, ${ }^{70}$ but consistent with a recent report that lovastatin-induced thyroid cell apoptosis is not accompanied by 553 or bax induction. ${ }^{18}$ Since bax gene has been identified as a p53-immediate early response gene, ${ }^{49}$ the expression of which serves as a useful marker for p53-dependent apoptosis, ${ }^{50-52}$ lovastatin-induced apoptosis in medulloblastoma cells is probably p53-independent. To support this view, lovastatin does induce apoptosis in other tumor cell lines and primary tumors through p53-independent pathways. ${ }^{39,42,68,71}$

p53 can also induce apoptosis without initiating de novo protein or RNA synthesis, ${ }^{72,73}$ and both wild-type and mutant p53 can promote exit from ionizing-radiation induced G2 arrest resulting in apoptosis. ${ }^{74,75}$ Direct protein-protein interactions involving p53 could represent the nontransactivitional mechanism for p53 regulation of apoptosis. It is therefore possible that this, or an alternative p53-dependent mechanism, may be involved in lovastatin-induced apoptosis in medulloblastoma. Whether lovastatin pretreatment of medulloblastoma may enhance sensitivity to tumour necrosis factor (TNF)-related apoptosis-inducing ligand (TRAIL), as has previously been documented for certain systemic cancers, ${ }^{76}$ remains to be determined.

p53 protein may contribute to growth inhibition and apoptosis 
through inducing $p 21^{\text {WAF1 }}$ expression. ${ }^{33-35}$ In D341 Med cell line, the induction of both $\mathrm{p} 53$ and $\mathrm{p} 21^{\mathrm{WAF} 1}$ protein accompanied lovastatin treatment, raising the possibility that $\mathrm{p} 53$ may regulate lovastatin-induced growth inhibition in this case through the regulation of $p 21^{W A F 1}$ gene expression. In Daoy cell line, p21 WAF1 protein, but not $\mathrm{p} 53$, was induced in lovastatin treatment, possibly due to the high level of background of p53. However, since $p 21^{W A F 1}$ gene expression could also be p53-independent, for example, in TGF- $\beta$ induced cell cycle arrest, ${ }^{33-35}$ it is possible this is the case in Daoy.

Collectively, the data presented here demonstrate that lovastatin-induced growth inhibition and apoptosis in medulloblastoma are not dependent on the regulation of Ras and $c$-myc gene expression, but may be mediated by $p 27^{K I P I}$ gene expression. Lovastatin-induced apoptosis in medulloblastoma is probably p53 independent, but $p 53$ and $p 21^{W A F 1}$ gene expression may also mediate antiproliferative effects of lovastatin on specific medulloblastoma cell lines.

\section{ACKNOWLEDGEMENTS}

This study was partially funded by the Health Services Utilization and Research Commission of Saskatchewan, and partially by the Brain Tumor Research Foundation of Canada.

\section{REFERENCES}

1. Jay V, Becker LE. Brain tumors. Curr Opin Neurol Neurosurg 1990;3:934-942.

2. Packer RJ, Sutton LN, Elterman R, et al. Outcome for children with medulloblastoma treated with radiation and cisplatin, $\mathrm{CCNU}$, and vincristine chemotherapy. J Neurosurg 1994;81:690-698.

3. Rorke LB, Trojanowski JQ, Lee VM, et al. Primitive neuroectodermal tumors of the central nervous system. Brain Pathol 1997;7:765-784.

4. Tomlinson FH, Scheithauer BW, Meyer FB, et al. Medulloblastoma: I. Clinical, diagnostic, and therapeutic overview. J Child Neurol 1992;7:142-155.

5. Nishiyama K, Funakoshi S, Izumoto S, et al. Long-term effects of radiation for medulloblastoma on intellectual and physical development. A case report of monozygotic twins. Cancer 1994;73:2450-2455.

6. Packer RJ. Chemotherapy for medulloblastoma/primitive neuroectodermal tumors of the posterior fossa. Ann Neurol 1990;28:823-828.

7. Tishler DM, Weinberg KI, Sender LS, et al. Multidrug resistance gene expression in pediatric primitive neuroectodermal tumors of the central nervous system. J Neurosurg 1992;76:507-512.

8. Cohen BH, Zweidler P, Goldwein JW, et al. Ototoxic effect of cisplatin in children with brain tumors. Pediatr Neurosurg 1990;16:292-296.

9. Torres CF, Rebsamen S, Silber JH, et al. Surveillance scanning of children with medulloblastoma [see comments]. N Engl J Med 1994;330:892-895.

10. Tobert JA, Hitzenberger G, Kukovetz WR, et al. Rapid and substantial lowering of human serum cholesterol by mevinolin (MK-803), an inhibitor of hydroxymethylglutaryl-coenzyme A reductase. Atherosclerosis 1982;41:61-65.

11. Keyomarsi K, Sandoval L, Band V, et al. Synchronization of tumor and normal cells from G1 to multiple cell cycles by lovastatin. Cancer Res 1991;51:3602-3609.

12. Sumi S, Beauchamp RD, Townsend CJ, et al. Inhibition of pancreatic adenocarcinoma cell growth by lovastatin. Gastroenterology 1992;103:982-989.

13. Macaulay RJB, Wang W, Dimitroulakos J, et al. lovastatin-induced apoptosis of human medulloblastoma cell lines in vitro. J Neurooncol 1999;42:1-11.

14. Wang W, Macaulay RJB. Apoptosis of medulloblastoma cells in vitro follows inhibition of farnesylation using manumycin A. Int J Cancer 1999;82:430-434.

15. Bansal N, Houle AG, Melnykovych G. Comparison of dexamethasone and lovastatin (mevinolin) as growth inhibitors in cultures of T-cell derived human acute leukemia lines (CEM). Leuk Res 1989;13:875-882.

16. Perez SD, Mollinedo F. Inhibition of isoprenoid biosynthesis induces apoptosis in human promyelocytic HL-60 cells. Biochem Biophys Res Commun 1994;199:1209-1215.

17. Jones KD, Couldwell WT, Hinton DR, et al. Lovastatin induces growth inhibition and apoptosis in human malignant glioma cells. Biochem Biophys Res Commun 1994;205:1681-1687.

18. Di Matola T, D'Ascoli F, Luongo C, et al. Lovastatin-induced apoptosis in thyroid cells: involvement of cytochrome c and lamin B. Eur J Endocrinol 2001;145:645-650.

19. Feleszko W, Mlynarczuk I, Olszewska D, et al. Lovastatin potentiates antitumor activity of doxorubicin in murine melanoma via an apoptosis-dependent mechanism. Int $\mathbf{J}$ Cancer 2002;100:111-118.

20. Larner J, Jane J, Laws E, et al. A phase I-II trial of lovastatin for anaplastic astrocytoma and glioblastoma multiforme. Am J Clin Oncol 1998;21:579-583.

21. Kim WS, Kim MM, Choi HJ, et al. Phase II study of high-dose lovastatin in patients with advanced gastric adenocarcinoma. Invest New Drugs 2001;19:81-83.

22. Wang W, Macaulay RJB. Mevalonate prevents lovastatin-induced apoptosis in medulloblastoma cell lines. Can J Neurol Sciences 1999;26:305-310.

23. Kohl NE, Conner MW, Gibbs JB, et al. Development of inhibitors of protein farnesylation as potential chemotherapeutic agents. J Cell Biochem (Suppl) 1995;22:145-150.

24. Dimster DD, Schafer WR, Rine J. Control of RAS mRNA level by the mevalonate pathway. Mol Biol Cell 1995;6:59-70.

25. Holstein SA, Wohlford-Lenane CL, Hohl RJ. Consequences of mevalonate depletion. Differential transcriptional, translational, and post-translational up-regulation of Ras, Rapla, RhoA, and RhoB. J Biol Chem 2002;277:10678-10682.

26. Barbacid M. ras genes. Annu Rev Biochem 1987;56:779-827.

27. Bigner SH, Friedman HS, Vogelstein B, et al. Amplification of the $c$-myc gene in human medulloblastoma cell lines and xenografts [published erratum appears in Cancer Res 1990 Jun 15;50(12):3809]. Cancer Res 1990;50:2347-2350.

28. Friedman HS, Burger PC, Bigner SH, et al. Phenotypic and genotypic analysis of a human medulloblastoma cell line and transplantable xenograft (D341 Med) demonstrating amplification of $c$-myc. Am J Pathol 1988;130:472-484.

29. Askew DS, Ashmun RA, Simmons BC, et al. Constitutive $c$-myc expression in an IL-3-dependent myeloid cell line suppresses cell cycle arrest and accelerates apoptosis. Oncogene 1991;6:19151922.

30. Evan GI, Wyllie AH, Gilbert CS, et al. Induction of apoptosis in fibroblasts by c-myc protein. Cell 1992;69:119-128.

31. Hermeking H, Eick D. Mediation of c-myc-induced apoptosis by p53. Science 1994;265:2091-2093.

32. Park C, Lee I, Kang WK. Lovastatin-induced E2F-1 modulation and its effect on prostate cancer cell death. Carcinogenesis 2001;22:1727-1731.

33. Grana X, Reddy EP. Cell cycle control in mammalian cells: role of cyclins, cyclin dependent kinases (CDKs), growth suppressor genes and cyclin-dependent kinase inhibitors (CKIs). Oncogene 1995; 11:211-219.

34. Hall M, Peters G. Genetic alterations of cyclins, cxyclin-dependent kinase, and Cdk inhibitors in human cancer. Adv Cancer Res 1996;68:67-108

35. Sherr CJ. Cancer cell cycles. Science 1996;274:1672-1677.

36. Sherr CJ, Roberts JM. Inhibitors of mammalian G1 cyclindependent kinases. Genes Dev 1995;9:1149-1163.

37. Hengst L, Reed SI. Translational control of p27Kip1 accumulation during the cell cycle. Science 1996;271:1861-1864.

38. Poon RY, Toyoshima H, Hunter T. Redistribution of the CDK inhibitor p27 between different cyclin. CDK complexes in the mouse fibroblast cell cycle and in cells arrested with lovastatin or ultraviolet irradiation. Mol Biol Cell 1995;6:1197-1213. 
39. Rao S, Lowe M, Herliczek TW, et al. Lovastatin mediated G1 arrest in normal and tumor breast cells is through inhibition of CDK2 activity and redistribution of p21 and p27, independent of p53. Oncogene 1998;17:2393-2402.

40. Gray-Bablin J, Rao S, Keyomarsi K. Lovastatin induction of cyclindependent kinase inhibitors in human breast cells occurs in a cell cycle-independent fashion. Cancer Res 1997;57:604-609.

41. Giermasz A, Makowski M, Kozlowska E, et al. Potentiating antitumor effects of a combination therapy with lovastatin and butyrate in the Lewis lung carcinoma model in mice. Int J Cancer 2002;97:746-750.

42. Lee SJ, Ha MJ, Lee J, et al. Inhibition of the 3-hydroxy-3methylglutaryl-coenzyme A reductase pathway induces p53independent transcriptional regulation of $\mathrm{p} 21\left({ }^{\text {WAF } / / \mathrm{CIP1}}\right)$ in human prostate carcinoma cells. J Biol Chem 1998;273:10618-10623.

43. Vidal A, Millard SS, Miller JP, et al. Rho activity can alter the translation of p27 mRNA and is important for RasV12-induced transformation in a manner dependent on p27 status. J Biol Chem 2002;277:16433-16440.

44. Cohen JJ, Duke RC. Glucocorticoid activation of a calciumdependent endonuclease in thymocyte nuclei leads to cell death. J Immunol 1984;132:38-42.

45. Levine AJ, Momand J, Finlay CA. The p 53 tumour suppressor gene. Nature 1991;351:453-456.

46. Yonish RE, Resnitzky D, Lotem J, et al. Wild-type p53 induces apoptosis of myeloid leukaemic cells that is inhibited by interleukin-6. Nature 1991;352:345-347.

47. Kastan MB, Onyekwere O, Sidransky D, et al. Participation of p53 protein in the cellular response to DNA damage. Cancer Res 1991;51(23 Pt 1):6304-6311.

48. Oltvai ZN, Milliman CL, Korsmeyer SJ. Bcl-2 heterodimerizes in vivo with a conserved homolog, Bax, that accelerates programmed cell death. Cell 1993;74:609-619.

49. Miyashita T, Reed JC. Tumor suppressor p53 is a direct transcriptional activator of the human bax gene. Cell 1995;80:293-299.

50. Yin C, Knudson CM, Korsmeyer SJ, et al. Bax suppresses tumorigenesis and stimulates apoptosis in vivo. Nature 1997;385:637-640.

51. Grasso L, Mercer WE. Pathways of p53-dependent apoptosis. Vitam Horm 1997;53:139-173.

52. Liebermann DA, Hoffman B, Steinman RA. Molecular controls of growth arrest and apoptosis: p53-dependent and independent pathways. Oncogene 1995;11:199-210.

53. Keles GE, Berger MS, Srinivasan J, et al. Establishment and characterization of four human medulloblastoma-derived cell lines. Oncol Res 1995;7:493-503.

54. Heikkila R, Schwab G, Wickstrom E, et al. A c-myc antisense oligodeoxynucleotide inhibits entry into $\mathrm{S}$ phase but not progress from G0 to G1. Nature 1987;328:445-449.

55. Wickstrom EL, Bacon TA, Gonzalez A, et al. Human promyelocytic leukemia HL-60 cell proliferation and c-myc protein expression are inhibited by an antisense pentadecadeoxynucleotide target against $c$-myc mRNA. Proc Natl Acad Sci USA 1988;85:10281032

56. Holt JT, Redner RL, Nienhuis AW. An oligomer complementary to c-myc mRNA inhibits proliferation of HL-60 promyelocytic cells and induces differentiation. Mol Cell Biol 1988;8:963-973.

57. Koster R, Blatt LM, Streubert M, et al. Consensus-interferon and platelet-derived growth factor adversely regulate proliferation and migration of kaposi's sarcoma cells by control of $c$-myc expression. Am J Pathol 1996;149:1871-1885.

58. Kaptein JS, Lin CKE, Wang CL, et al. Anti-IgM-mediated regulation of $c-m y c$ and its possible relationship to apoptosis. $\mathrm{J}$ Biol Chem 1996;271:18875-18884.

59. Magee AI, Gutierrez L, McKay IA, et al. Dynamic fatty acylation of p21N-ras. EMBO J 1987;6:3353-3357.

60. Schafer WR, Kim R, Sterne R, et al. Genetic and pharmacological suppression of oncogenic mutations in ras genes of yeast and humans. Science 1989;245:379-385.

61. Leonard S, Beck L, Sinensky M. Inhibition of isoprenoid biosynthesis and the post-translational modification of pro-p21. J Biol Chem 1990;265:5157-5160.

62. Mangues R, Corral T, Kohl NE, et al. Antitumor effect of a farnesyl protein transferase inhibitor in mammary and lymphoid tumors overexpressing $\mathrm{N}$-ras in transgenic mice. Cancer Res 1998;58:1253-1259.

63. Whyte DB, Kirschmeier P, Hockenberry TN, et al. $K$ - and $N$-Ras are geranylgeranylated in cells treated with farnesyl protein transferase inhibitors. J Biol Chem 1997;272:14459-14464.

64. Green DR, Mahboubi A, Nishioka W, et al. Promotion and inhibition of activation-induced apoptosis in T-cell hybridomas by oncogenes and related signals. Immunol Rev 1994;142:321342.

65. Duffy MJ. Cellular oncogenes and suppressor genes as prognostic markers in cancer. Clin Biochem 1993;26:439-447.

66. Dimitroulakos J, Yeger H. HMG-CoA reductase mediates the biological effects of retinoic acid on human neuroblastoma cells: lovastatin specifically targets P-glycoprotein-expressing cells. Nat Med 1996;2:326-333.

67. Agarwal B, Halmos B, Feoktistov AS, et al. Mechanism of lovastatin-induced apoptosis in intestinal epithelial cells. Carcinogenesis 2002;23:521-528.

68. Vitale M, Di Matola T, Rossi G, et al. Prenyltransferase inhibitors induce apoptosis in proliferating thyroid cells through a p53independent $\mathrm{CrmA}$-sensitive, and caspase-3-like proteasedependent mechanism. Endocrinology 1999;140:698-704.

69. Laufs U, Marra D, Node K, et al. 3-Hydroxy-3-methylglutaryl-CoA reductase inhibitors attenuate vascular smooth muscle proliferation by preventing rho GTPase-induced down-regulation of p27(Kip1). J Biol Chem 1999;274:21926-21931.

70. Tanaka T, Tatsuno I, Uchida D, et al. Geranylgeranyl-pyrophosphate, an isoprenoid of mevalonate cascade, is a critical compound for rat primary cultured cortical neurons to protect the cell death induced by 3-hydroxy-3-methylglutaryl-CoA reductase inhibition. J Neurosci 2000;20:2852-2859.

71. Borner MM, Myers CE, Sartor O, et al. Drug-induced apoptosis is not necessarily dependent on macromolecular synthesis or proliferation in the p53-negative human prostate cancer cell line PC-3. Cancer Res 1995;55:2122-2128.

72. Caelles C, Helmberg A, Karin M. p53-dependent apoptosis in the absence of transcriptional activation of p53-target genes [see comments]. Nature 1994;370:220-223.

73. Wagner AJ, Kokontis JM, Hay N. Myc-mediated apoptosis requires wild-type p53 in a manner independent of cell cycle arrest and the ability of p53 to induce p21waf1/cip1. Genes Dev 1994;8:28172830.

74. Guillouf C, Rosselli F, Sjin RT, et al. Role of a mutant p53 protein in apoptosis: characterization of a function independent of transcriptional trans-activation. Int J Oncol 1998;13:107-114.

75. Guillouf C, Rosselli F, Krishnaraju K, et al. p53 involvement in control of G2 exit of the cell cycle: role in DNA damage-induced apoptosis. Oncogene 1995;10:2263-2270.

76. Jin Z, Dicker, DT, El-Deiry WS. Enhanced sensitivity of G1 arrested human cancer cells suggests a novel therapeutic strategy using a combination of simvastatin and TRAIL. Cell Cycle 2002; 1:82-89. 